\title{
Facebook
}

\section{Fra socialt netværk til metamedie}

\author{
Anmeldelse af Lars Konzack
}

Jensen, Jakob Linaa og Takke, Jesper (red) (2013). Facebook: Fra socialt netvark til metamedie. Samfundslitteratur. Medvirkende forfattere: Niels Brügger, Lisbeth Klastrup, Jesper Takke, Stine Lomborg, Anne Scott Sørensen, Anna Katrine Skall Sørensen, Malene Charlotte Larsen, Jakob Linaa Jensen, Henrik Bødker, Lars Holmgaard Christensen, Jens Nielsen og Søren Dahm.

Facebook har slået sig fast som danskernes som danskernes foretrukne sociale medie. Derfor er det også helt naturligt, at de førende danske forskere på området sætter sig sammen og får skrevet en bog, og det er der kommet en glimrende udgivelse ud af. Bogen er delt op i tre dele, nemlig 1) Facebook som mediefænomen, 2) Facebook og sociale relationer, og 3) Facebook og samfundet. Opdelingen er velfungerende og hjælper til at oveskue artiklerne og sætte dem i den rette kontekst.

Hvis vi ser på den første del om Facebook som mediefænomen, så består den først af en gennemgang af Facebooks historie efterfulgt af en analyse af danskernes brug af Facebook samt en mediesociologisk teoretisering.

Niels Brügger har påtaget sig opgaven at lave en historisk gennemgang af Facebook. Det giver anled-

Lars Konzack, lektor, Københavns Universitet, Det Informationsvidenskabelige Akademi (mtw296@iva.ku.dk) ning til at give en grundlæggende gennemgang af funktionaliteten i Facebook, hvad angår, hvordan man opretter en profil og får et netværk af venner, hvordan deling og kontaktskaben fungerer, samt hvordan reklamer er folkene bag Facebooks indtægtskilde. Niels Brügger forklarer, at på de knap ti år Facebook har eksisteret, er den sket en udvikling med nye profil og netværksmuligheder herunder mulighed for at bruge mobiltelefon. Her gives også et godt overblik over, de ekstra udvidelsesmuligheder som Facebook modulært har udviklet over tid. Kapitlet fungerer tilfredsstillende som introduktion til emnet.

Hvor Niels Brügger anlægger et generelt globalt perspektiv på mediet, anskuer Lisbeth Klastrup Facebook fra et nationalt dansk perspektiv og stiller spørgsmål til, hvor vidt danskerne er blevet globale borgere med Facebook eller foretrækker, at have en tættere national omgangskreds. Ud fra en online spørgeskema-undersøgelse fra 2010 baseret på over 700 svar, når hun frem til, at dansk er det langt mest brugte sprog - og ikke overraskende er det næstmest brugte sprog engelsk. Facebook fungerer for danskerne som en ø på det globale internet. Hvor Niels Brügger fokuserede på mediet, så anlægger dette udmærkede studie et mediesociologisk perspektiv. Første del, Facebook som mediefænomen, afsluttes med Jesper Tækkes overvejelser om, hvordan Facebook giver anledning til social ambivalens. Kapitlet svækkes lidt af tung medieteoretisk tilgang, der er lige ved at komme i vejen for budskabet. Når det sagt, så har Jesper Tække en god pointe, nemlig 
at det kan være ganske uklart, hvordan det sociale netværk fungerer, fordi man ikke har adgang til de algoritmer eller beslutninger, der har konsekvens for, hvordan ejerne af Facebook vælger at dele indhold mellem brugerne i netværket. Det er uigennemskueligt, hvad der foregår, og der kan pludselig blive ændret i, hvordan delingen i netværket foregår.

Næste del handler om de sociale relationer. Det er der for så vidt allerede taget hul på i et par af de første artikler, og det forekommer derfor en smule uklart, hvori opdelingen mellem første del og anden del består, fordi anden del ligeledes har et mediesociologisk perspektiv og diskuterer Facebook som medie, og de muligheder det giver.

Den første artikel i anden del er skrevet af Stine Lomborg, der skriver om genreforhandling som kommunikativ praksis. Det er en udredning af hvilke genrer, der er til stede på Facebook, og hvordan brugerne ind imellem har brug for at forhandle sig frem til en fælles forståelse. Det er baseret på femten semi-strukturerede interviews foretaget i perioden 2008-2012 af næsten lige mange mænd og kvinder i alderen 25-59 år. Her får vi nogle umiddelbare oplevelser af, hvordan det er at være (ny) bruger af Facebook. Det giver naturligvis et vist indblik i, hvordan forskellige mennesker bruger mediet, men de fleste pointer kunne man for så vidt have opnået gennem en medieanalytisk tilgang.

Anne Scott Søresen foretager en kommunikativ analyse baseret på et survey. Artiklen giver et mediesociologisk indblik i, hvordan brugerne af Facebook kommunikerer baseret på sociale spilleregler, normdannelse og social regulering. Det vil se, hvad man kan tillade sig at sige og bruge mediet til. Fokus ligger på selvfremstilling, smalltalk og hyggesnak - og selvom der nok også er meget af den slags, så kunne der godt være en diskussion af, om der ikke er andre tilgange til brug af mediet end netop det nære og det selviske. Men heldigvis bliver der dog rådet bod på det i senere kapitler.

Anna Katrine Skall Sørensen tager den oplagte diskussion om, hvad der ligger i begrebet venner og venskab i henhold til Facebooks brug af netop denne term til at udpege et netværk. Alt efter, hvordan man bruger Facebook, er mange af 'vennerne' i Facebook jo ikke venner i den almindelige brug af ordet. Mange er bekendte - og der kan endog optræde folk, som man slet ikke kender. Artiklen bygger på en diskurs- og handlingsanalyse brugt på en dataindsamling bestående af deltagerobservation og kvalitative interviews. Det handler om identitet og venskab, og der konkluderes, at venskabet for netgenerationen ikke er i krise, hvilket jo er godt nok og formodentligt sandt, men artiklen når desværre ikke ret meget videre end det.

Spørgsmålet om identitetsdannelse bliver taget op af Malene Charlotte Larsen, der har undersøgt danske unges brug af Facebook. Hun baserer sig på en såkaldt neksusanalyse, der er en kombination etnografisk metodologisk strategi og diskursanalyse. Dette følges op en nødvendig diskussion af identitetsbegrebet, der siden postmodernismens indtog er blevet et meget forvirrende begreb - ja nærmest ubrugeligt, fordi det tilsyneladende undlader sig enhver bestemmelse. Malene Charlotte Larsen undgår nogle af de værste fælder, og undersøger konkret unges brug af likes, ros som gensidigt bytteforhold og plæderer endeligt for en slags open source-identitet.

Sidste del handler om Facebook og samfundet - og her når det ud over det nære og ser Facebook i en bredere sammenhæng.

Jakob Linaa begynder denne sidste del af bogen med at redegøre for offentlighedsbegrebet og sætte det $\mathrm{i}$ relation til Facebook som en slags borgerlig offentlighed. Det fører til en undersøgelse af internationale og danske erfaringer, hvad angår sociale medier og politisk deltagelse. De danske erfaringer tager udgangspunkt i to undersøgelser af brugen af sociale medier i politisk øjemed fra Folketingsvalget i 2007 og Folketingsvalget i 2001. Facebook bliver set som en mobiliserende kraft, der dog samtidig underminerer offentlighedens sammenhængskraft.

Henrik Bødker ser på de sociale medier som journalistisk kommentarfilter. Her bryder de sociale medier i nogen grad med de sorteringsmekanismer, som aviserne hidtil har haft. Ved at brugerne selv deler de artikler og diskuterer dem, skaber den journalistiske praksis en ny social filtreringsproces, og det giver nye fortolkningsrammer for brugerne. Henrik Bødker beskriver også fænomenet professionel trolling. Dette er nok den artikel, der har det mest interessante perspektiv på, hvad Facebook kan som medie. 
Perspektivet følges op af Lars Holmgaard Christensen, der anskuer Facebook som nyhedskanal og filosoferer lidt frit over det sociales nyhedsværdi med udgangspunkt i projektet Nyhedernes Sociale Angst. Her vises, hvordan nyhedsbrug ikke blot kan fungere som viralt indhold, men også skabe vennerelationer.

Endelig har Jens Nielsen og Søren Dahm set på Facebook som krisekommunikation. De tager forskellige eksempler op, hvor Facebooks netværk vender sig i fællesskab mod en virksomhed, der har behandlet deres kunder dårligt. Her diskuteres ikke så meget rimeligheden af denne reaktion, men i stedet vælges et traditionelt organisations- og virksomhedsperspektiv, hvor der gives råd til, hvordan organisa- tionen eller virksomheden overkommer problemerne med effektiv kommunikation.

Alt $i$ alt er det en vellykket bog om Facebook. Det hjælper, at man har valgt et så klart emneområde, så artiklerne ikke stikker ud i alle retninger. Men det har måske den uheldige virkning, at mange artikler kommer til at gentage de samme pointer om funktionaliteten i Facebook. Det kan man dog godt tilgive, fordi der er anlagt så mange forskellige perspektiver. Der skal også gå en lykønskning til redaktørerne for udvalget af artikler, og det er lykkedes dem at bringe nogen af de førende forskere indenfor dette felt sammen i en fremragende udgivelse. 